\title{
Implementasi Flex Sensor Dan Wireless Module Sebagai Alat Bantu Pasien Afasia Motorik
}

\author{
Halifia Hendri, Harkamsyah Andrianof, Okta Andrica Putra, Hasri Awal, Dendi Novrizal \\ 1,2,3,4,5 Faculty Ilmu Komputer, Universitas Putra Indonesia YPTK Padang, Indonesia \\ Halifia_hendri@upiyptk.ac.id, Harkamsyah.andrianof@upiyptk.ac.id, okta.andrica@gmail.com \\ hasriawal@upiyptk.ac.id, dendi.novrizal@upiyptk.ac.id
}

\begin{abstract}
In the era of technology developing rapidly as it is today, of course, there are many new things being done by the health sector. As a form of convenience in the health sector. With that, the health sector utilizes and applies and develops existing technology as a tool to facilitate and support new adaptations. One of them is by implementing a motor aphasia patient communication system that utilizes the basics of hand kinematics with nurses. This study was conducted aimed at motor aphasia patients and nurses in the health sector. The system is used as a communication tool between motor aphasia patients and nurses. The tool is equipped with a sensor flex as input expenditure command aphasia patient motor by utilizing the basic kinematics of the hand which will then be sent via wireless to the hardware nurse who later dihardware nurses as the output will be sounding the command through the speakers is detected by the sensor flex
\end{abstract}

Keywords: Communication system, Arduino, Flex, NRF24L01, Speaker

\section{INTRODUCTION}

Strokes can have a negative impact on one's quality of life. Because, in addition to leaving a disability in the form of paralysis, a stroke also causes aphasia, a linguistic issue. Aphasia is a condition that arises when the left side of the brain is disrupted. The front region of the left brain is responsible for smoothly speaking the contents of the mind in good language, while the back half of the left brain is responsible for interpreting the language spoken by others. Aphasia is the loss of some or all of one's capacity to speak as a result of a brain disease, disability, or damage. Motor aphasia is a communication condition in which the patient is unable to communicate thoughts using words yet is able to interpret other people's speech and writing.
Barriers to patient communication might cause patients to become enraged. When it comes to communication, the patient's quick and poor pronunciation frequently confuses the family or nurse, producing aggravation for the patient. The use of a board with pictures or writing on which the patient can write or point to an image that is already present is one way to interact with aphasia sufferers. Drawing or writing board communication, on the other hand, is deemed less effective because both the nurse and the patient must match the patient's intentions, which takes a long time to comprehend. Motor aphasia is a communication condition in which the patient is unable to communicate thoughts using words yet is able to interpret other people's speech and writing. The drawing 
board communication approach is a challenge for the nurse since, in addition to comprehending the patient's requests, it necessitates the nurse remaining near the patient at all times

Disabled post-stroke patients will find it difficult to carry out regular duties, particularly conversing with others. The quality of life of post-stroke patients suffers as a result of this. Post-stroke patients must undergo therapy in order to communicate, but this procedure takes time. As a result, a communication tool for post-stroke sufferers was developed in this study.

The impairment experienced by those who have had a stroke and have aphasia or dysarthria was chosen. This post-stroke patient retains normal cognitive function but struggles to communicate effectively. The next stage is to determine how the stroke victim can communicate again.

\section{RESEARCH METHOD}

The framework outlines the measures that will be done to tackle the situation at hand. The framework for this study is shown in Figure 3.1 below.

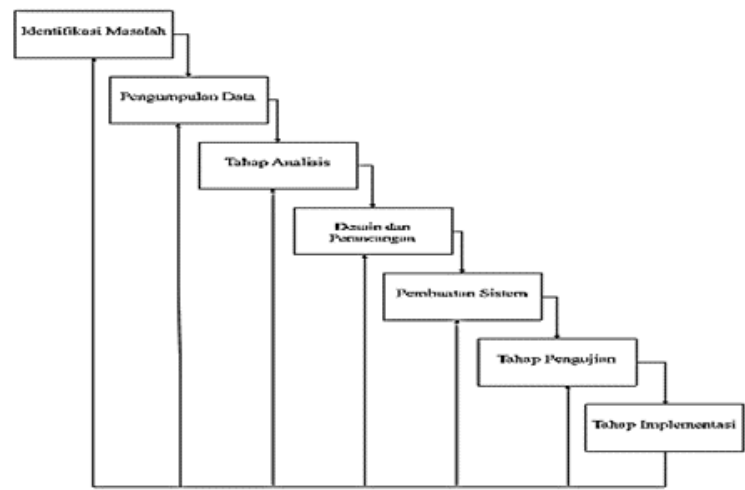

Figure 1. Description of Research Framework The following are the steps in completing this research:

A. Identification of problems
Approaching the study object allows for the identification of problems. The goal of this stage is to identify the difficulties that arise in an acceptable manner, so that research may give the best answer to these issues.

The issue that has been noticed is that aphasic patients find it difficult to interact with nurses using a technology that uses kinematic hand motions. This can be addressed with current technical advancements by creating a glove with commands on some of the patient's fingers using an Arduino microcontroller

\section{B. Data collection}

The authors employ the following research methodology based on the approach used during the study process to gather correct data, as well as in creating tools and working on this report :

- Library Research

- Laboratory Research

- Field Research

\section{System Analysis}

The analysis stage is the most important stage in the development of a system, based on the identification of the problem above; in this analysis, the researcher wants to explain the inputs, outputs, and processes of the system to be made; it is intended that problem solving can produce a new solution. The data was evaluated by the researchers based on the above-mentioned problem identification. This is so that prior to designing a tool, issue solving might provide a new solution.

\section{System Design}

Starting with the software technique employed in this study, which is based on the notion of a structured approach, we will construct a system design that will operate at this level. This 
notion involves modeling in a standardized and methodical manner by following a set of stages. The objective is to produce meaningful information and suit the demands of the users.

\section{E. System Creation}

All of the obtained data and research will be processed, and all of the primary and supporting components will be built based on the concepts produced and the tools (context diagrams, flowcharts, and data flow diagrams) used in the activity process. Following the assembly of the system, the entire program input procedure is carried out using the Arduino IDE application so that the tool's condition may run as intended

F. System Test

System testing is the process of identifying and correcting problems in a system. It might be input mistakes, outputs, or procedures that aren't working as they should. The system produced should have lower error rates as a result of the testing.

\section{G. Implementation}

The stage of putting the system together so that it is ready to use is known as system implementation. The embodiment of the system that was constructed, or whether the system was able to be implemented and run as the researcher wanted, is also a factor in system implementation. This is required in order for users to be able to use the tools that have been created to meet their needs. The goal of implementation is to examine how well the tool is designed to meet the goals and to detect any problems that arise in the system

\subsection{General Design}

In most cases, it is required to thoroughly specify the system that will be created in advance during the analytic phase. This implies that the scope of the conversation must be clearly defined.

\section{A. Context Diagram}

Context diagrams serve as media, containing a process and a number of external elements. In the Figure 2 and 3, you can see the context diagram in question.

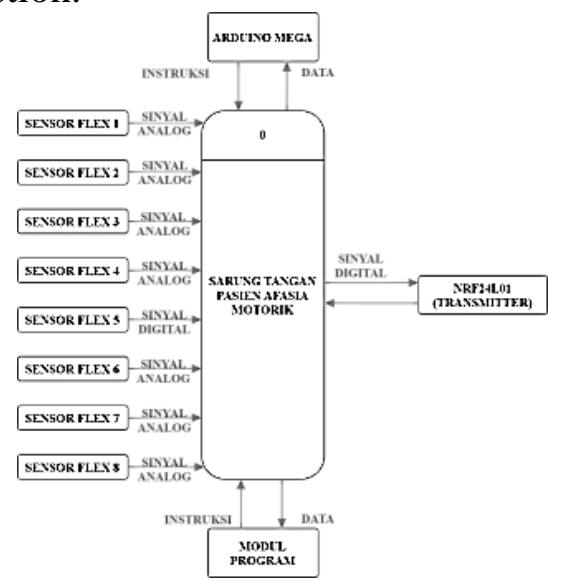

Figure 2. Context Diagram (gloves)

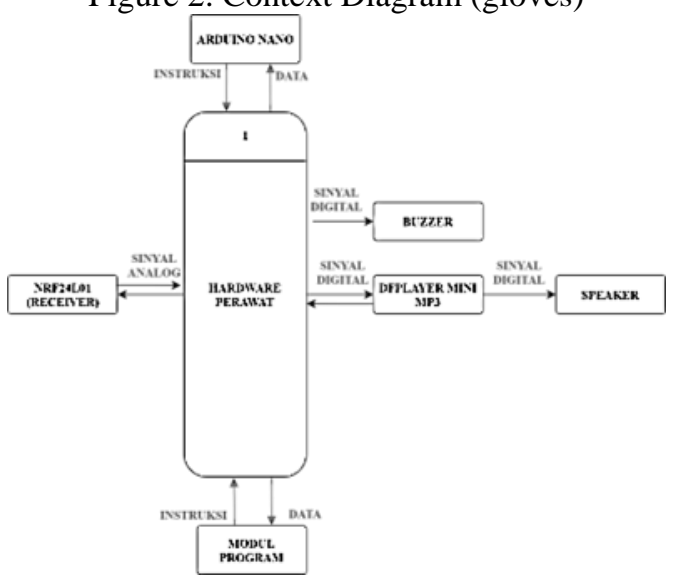

Figure 3. Context Diagram (Hardware Perawat)

B. Data Flow Diagram (DFD)

A data flow diagram provides a more complete explanation of the tool that has been built. The context diagram that was previously explained is used to

\section{RESULTS AND DISCUSSION}


describe the data flow diagram. Figure 4 shows a data flow diagram for images:

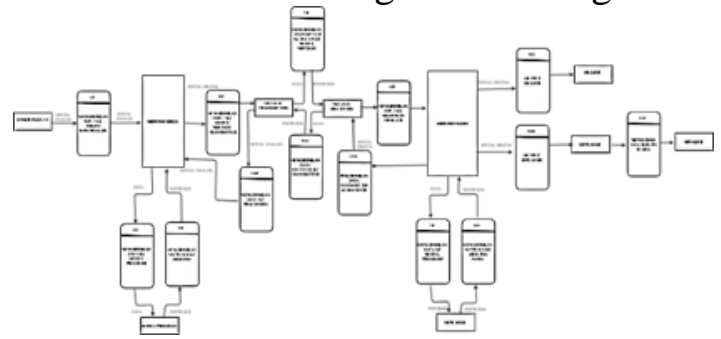

Figure 4. Data Flow Diagram

\section{Block Diagram}

In the Figure 5. The system is comprised of input, process, and output, as shown in the block diagram above. Microcontrollers such as the Arduino Mega and Arduino Nano serve as processing and control centers. The system uses a flex sensor as an input, an NRF24L01 module as a processing medium, and DfPlayer, Speaker, and Buzzer as outputs.

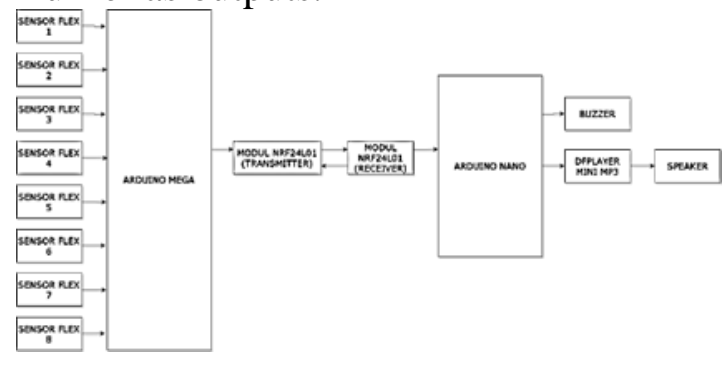

Figure 5. Block Diagram

\subsection{System Physical Design}

The physical design of the system is, in general, the first design form of the hardware that will be created. The following is an example of the system design that has to be created in figure 6 :

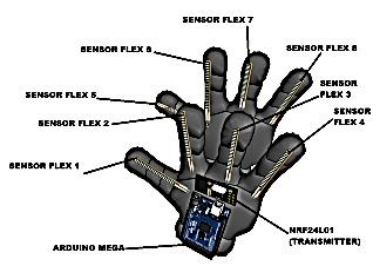

Figure 6. Block Diagram

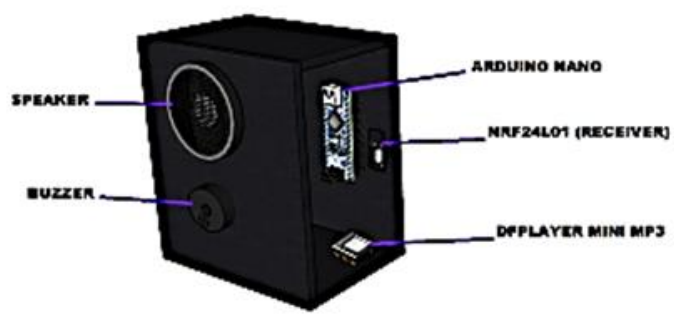

Figure 7. Hardware Nurse

The tool's physical design plays an important role in supporting the system, as seen in Figures 6 and 7. This tool's gadgets are controlled by Arduino Mega and Arduino Nano. Flex sensor is an input device for detecting motor aphasia patients' finger movements, NRF24L01 module for wirelessly transmitting data from motor aphasia patients' gloves to nurse hardware, Buzzer, and DFPlayer mini MP3 functions as output for sound notifications and commands in the form of voice if patients with motor aphasia want to communicate with nurses or families at any time

\subsection{Detailed System Design}

Per-module system designs can be used to demonstrate the detailed system design. The following are the designs for the per-module system:

A. Arduino Mega 2560 Circuit

The Arduino Mega 2560's minimal system circuit operates so that it may work as needed, with the design aiming to make the tool easier to use. The Arduino Mega 2560 circuit above runs the Arduino Mega 2560 so that it can operate as needed, with the goal of making the Arduino Mega 2560 easier to use. A $16 \mathrm{Mhz}$ crystal is also utilized in the aforementioned circuit, which may be used for serial transmission. On the reset pin, a circuit is required that acts as a reset for the Arduino Mega 2560 at the start of the system, with all of the Arduino Mega 2560's pins set to logic 0. As a 
result, initialization of the port is necessary at the start of programming.

B. Arduino nano Circuit

Arduino is a breadboard-compatible microcontroller board that is compact, comprehensive, and complete. The ATmega328 (for Arduino Nano version 3.x) or Atmega16 (for Arduino Nano version 2.x) microcontrollers are used in Arduino Nano. The Arduino Nano is similar to the Arduino Duemilanove in terms of capabilities, however it comes in a different packaging. The Arduino Nano does not include a Barrel Jacktype DC socket, and instead uses a Mini-B USB port to connect to a computer. Gravitech is the firm that created and manufactured the Arduino Nano

C. Dfplayer Mini MP3 Circuit

DFplayer small is an audio file player / sound player / music module that supports audio formats like.mp3 files. The micro mp3 module's output may be connected directly to mini speakers or amplifiers as loudspeakers. The RX and TX serial pins of the Arduino are used to link this module to the Arduino.

D. LCD Circuit

A flex sensor is employed in the design of this gadget to determine if there are any finger motions or orders sent by motor aphasia sufferers

E. NRF24L01 Module Circuit The NRF24L01 module is utilized to transfer data or information wirelessly in the design of this gadget.

\subsection{Program Module Design}

The program modules that control the system's work are described in this subchapter. The module design may be broken into two components to make it easier to understand: flowcharts and software modules.

\section{CONCLUSION}

Several conclusions may be formed based on the descriptions and explanations offered in the preceding chapters during the examination of the problems:

1. Instrument The flex sensor, NRF24L01 module, Arduino Mega 2560 Microcontroller, and Arduino Nano Microcontroller are all used in the implementation of the flex sensor on the communication tool for motoric aphasia patients.

2. Motor aphasia patients can operate effectively and properly by using a sensor that detects the curve of the finger, which is used to communication aids for motor aphasia patients.

3. The NRF24L01 wireless module, which acts as a transceiver, receiving and transmitting signals, will be processed in the program module, and the program module will send a digital signal to the Buzzer and Mini MP3 Dfplayer, ensuring that the output media performs properly and as it should.

4. Because the system is powered by rechargeable NICD batteries, the motor aphasia patient gloves and nursing hardware are portable.

\section{REFERENCES}

[1]. Abdul Kadir (2017). "Pemrograman Arduino Menggunakan ArduBlock". Yogyakarta: Andi. Hal 236.

[2]. Benny Pandapotan Siregar (2018). "Kalkulator Sederhana Menggunakan Keypad Dengan Output Speech Synthesizer dan Tampilan Pada LCD".Universitas Teknologi Yogyakarta:Skripsi. 
[3]. Cekmas Cekdin (2017), "Sistem Teknik Kendali", Hal 8.

[4]. Dr. Junaidi, S.Si., M.Sc Yulian Dwi Prabowo (2018). "Project Sistem Kendali Elektronik Berbasis Arduino"

[5]. Irwandi Tanjung (2017) "Perancangan Sistem Informasi Rekam Medis Terpadu Dalam Upaya Meningkatkan Pelayanan Rumah Sakit Jiwa Tampan Prov.Riau", Jurnal Intra-Tech, Vol 1,No 1,Hal. 43-54.

[6]. Irwandi Tanjung (2017)“Perancangan Sistem Informasi Rekam Medis Terpadu Dalam Upaya Meningkatkan Pelayanan Rumah Sakit Jiwa Tampan Prov.Riau". Jurnal Intra-Tech, Vol 1, No 1, Hal. 43-54.

[7]. Irwandi Tanjung (2017)“Perancangan Sistem Informasi Rekam Medis Terpadu Dalam Upaya Meningkatkan Pelayanan Rumah Sakit Jiwa Tampan Prov.Riau". Jurnal Intra-Tech, Vol 1, No 1, Hal. 43-54.

[8]. Medila Kusriyanto dan nendy wismoyo (2017). "Sistem Palang Pintu Perlintasan Kereta api Otomatis Dengan Komunikasi Wireless Berbasis Arduino" Universitas Islam Indonesia"

[9]. Muhammad Fajar Wicaksono, Hidayat (2017)." Mudah Belajar Mikrokontroller Arduino".

[10]. Retno Devita, Ruri Hartika, dan Tika Syafriani,(2020). "Pengontrolan Pola Dancing Founting Berirama Music Menggunakan Android Berbasis Mikrokontroler Arduino". Jurnal Teknologi
Informasi dan Pendidikan, Vol. 13, No. 1, Hal. 104-110).

[11]. Sutono, M.KOM (2017) "modul 1 Konsep Dasar Electronika"

[12]. Syaifi Abdurahman (2017) "modul electronica dan mechantronica dasar, serial revitalisasi SMK", Jakarta Hal 32.

[13]. Tata Sutabri (2016), "Sistem Informasi Manajemen (Edisi Revisi)", Hal : 2-3.

[14]. Tata Sutabri (2016), "Sistem Informasi Manajemen (Edisi Revisi)", Hal : 16-17.

[15]. Wahyu Satrio Prayogo, Muhamad Rifal, dan Fajar Budiman (2018).'Kontrol Lengan Robot Yang Meniru Pergerakan Tangan Untuk Inspeksi Objek Yang Mengandung Gas Berbahaya" Institut Sepuluh November.

[16]. H Hendri*, S. E. (2019). Automatic System to Fish Feeder and Water Turbidity. Journal of Physics: Conference Series, 3.

[17]. H Hendri, H. A. (2021). Solar-Cell Implementation for Supporting Tourist Facilities and Tourism Promotion Media. Journal of Physics: Conference Series, 1783.

[18]. Hendri, H. (2017). Sistem Kunci Pintu Otomatis Menggunakan RFID (Radio Frequency Identification) Berbasis Mikrokontroler Arduino Uno R3. Komputer Teknologi Informasi, 4.

[19]. Hendri, H. (2019). Pembersih Tangan Otomatis Dilengkapi Air, Sabun, Handdryer Dan Lcd Menggunakan Sensor Infrared Berbasis Arduino. TEKNOLOGI, 8. 